\title{
Lateral Surface of the Prostate
}

National Cancer Institute

\section{Source}

National Cancer Institute. Lateral Surface of the Prostate. NCI Thesaurus. Code C32949.

The aspect of the prostate facing the anterior portions of the Levatores ani muscles. 